\title{
New Beginnings in Romanian Political Life after the First World War
}

\author{
Marcela Sălăgean
}

At the beginning of the 20th century, the evolution of Romanian political life was influenced by several factors, the most important being the First World War, the Union of Transylvania, Bukovina and Bessarabia with the Romanian Kingdom, and the reforms adopted during and immediately following the war. These events all had important consequences for Romanian society, which had to face new challenges

RUMA N IEN

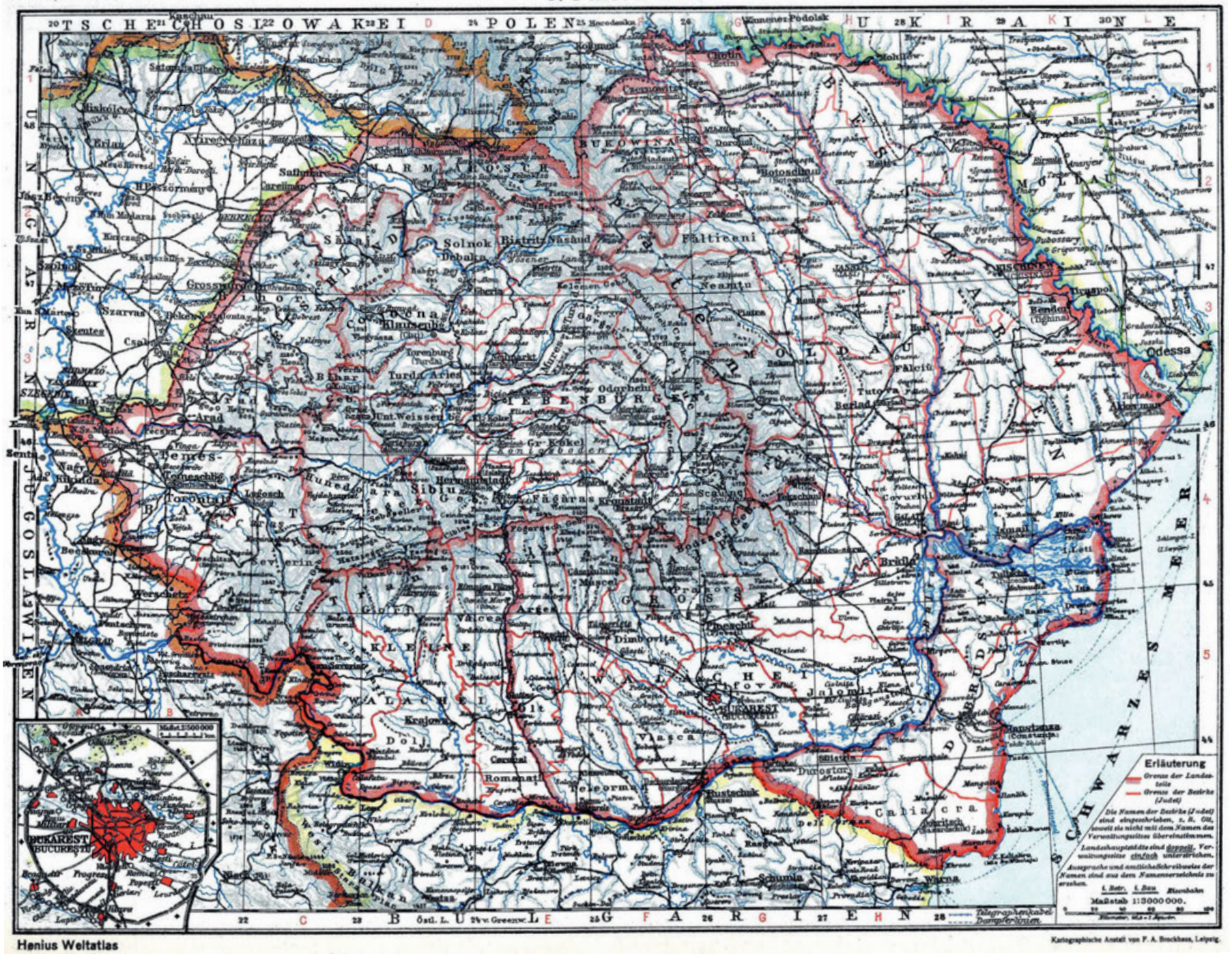

Fig. 1: Map of 'Greater Romania' with counties and historical regions, 1918. 
that altered the old social and political structures, giving birth to a very different Romania from the one that had existed before the outbreak of the war. ${ }^{1}$

It is well known that 'Greater Romania' had already become a physical reality before the Peace Treaty was signed, and one of the priorities the authorities faced was integrating the new territories, a process that often proved difficult even for the most experienced leaders. In fact, the need for national unity had a much more realistic basis than the euphoria generated by the idea of a Greater Romania. And the complexity of the problems to be solved was evident to all those involved in the process of integrating the united provinces, even before the administrative and institutional consolidation of the new state, which was to be multi-ethnic and multi-confessional, with more complex economic, political, social, and cultural structures than those of the Old Romanian Kingdom. ${ }^{2}$
The integration's success was all the more important as the accomplishment or failure of that process would impact the country's status and evolution, both domestically and internationally. Even though, as a whole, the administrative and legislative unification extended further than was originally thought, ending only at the end of the Second World War, the process was complex, engaging politicians as well as academics, lawyers, economists, and civil servants in debates and projects. ${ }^{3}$ They all agreed that Romania was starting to resemble Western Europe, but they could not decide on the paths that the country had to follow. Thus, several groups began to emerge, most significant among these being the Europeanists, the traditionalists, the agrarians, and the Marxists. For example, the Europeanists regarded Romania as a part of 'Europe', considering that the country had no choice but to follow the path of economic and social development taken by the urbanised and industri-

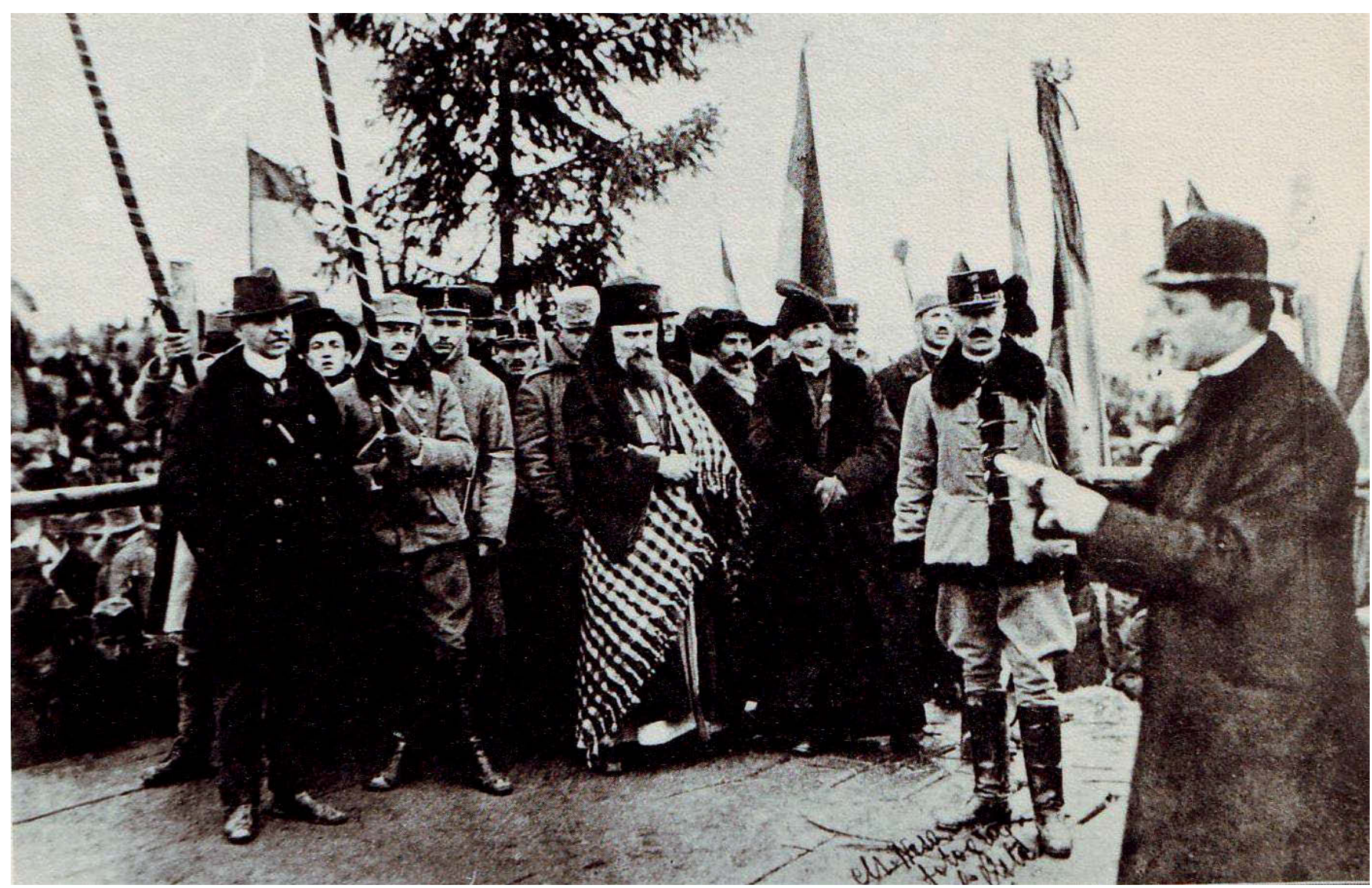

Fig. 2: Iuliu Hossu, Greek Catholic Bishop of Gherla, celebrates with dignitaries the declaration of unification of Transylvania, Bessarabia, and Bukovina with the Romanian Kingdom, Alba Iulia (Transylvania), 1 December 1918. 
alised West. The promoters of this trend argued that the decisive role in Romania's development was played by the indigenous bourgeoisie. Europeanism's opponents were the traditionalists. Lacking receptivity to any Western influences, they were looking for patterns of development in local traditions, in the heritage of the rural Romanian world and the Orthodox religion, and even in various influences coming from the Orient. They rejected the city, which they considered too abstract, and modern industry, which they found too rational, too inappropriate for the Romanians, a contemplative people, not accustomed to capitalist discipline. ${ }^{4}$

In the end, the Europeanists' view triumphed: the country needed to develop and modernise following the model of developed European countries. Intense legislative activity therefore began in 1918, with reforms promulgated by the government in Bucharest extended automatically throughout Greater Romania, although the local realities of the united provinces had to be taken into account. Programmes were adopted which stipulated the need for a new constitution, administrative and legislative unification, economic stability, and fundamental rights and freedoms for the citizens. Policymakers therefore developed several laws to strengthen the democratic regime: laws regarding freedom of the press, and freedom of association and assembly; laws regarding agricultural reform, education reform, and economic and administrative reforms; laws regarding rights for workers and ethnic minorities, freedoms for all religions and confessional groups recognised by the state, and many others. These were modern provisions that, once enacted alongside the Constitution adopted in 1923, formed the basis for the country's development and modernisation. ${ }^{5}$

Nevertheless, legislative activity that would bring the country progress in as many fields as possible could not exist in Romania without a political system able to reflect and find itself in the realities of the country following 1918. The formation of Greater Romania inevitably reshaped the political scene, and it was clear, as early as the beginning of 1919, that political live would be quite different from what it had been in the country before the war. The Union gave rise to new political parties and traditions, and electoral reform opened participation in politics up to a much greater number of citizens than ever be-

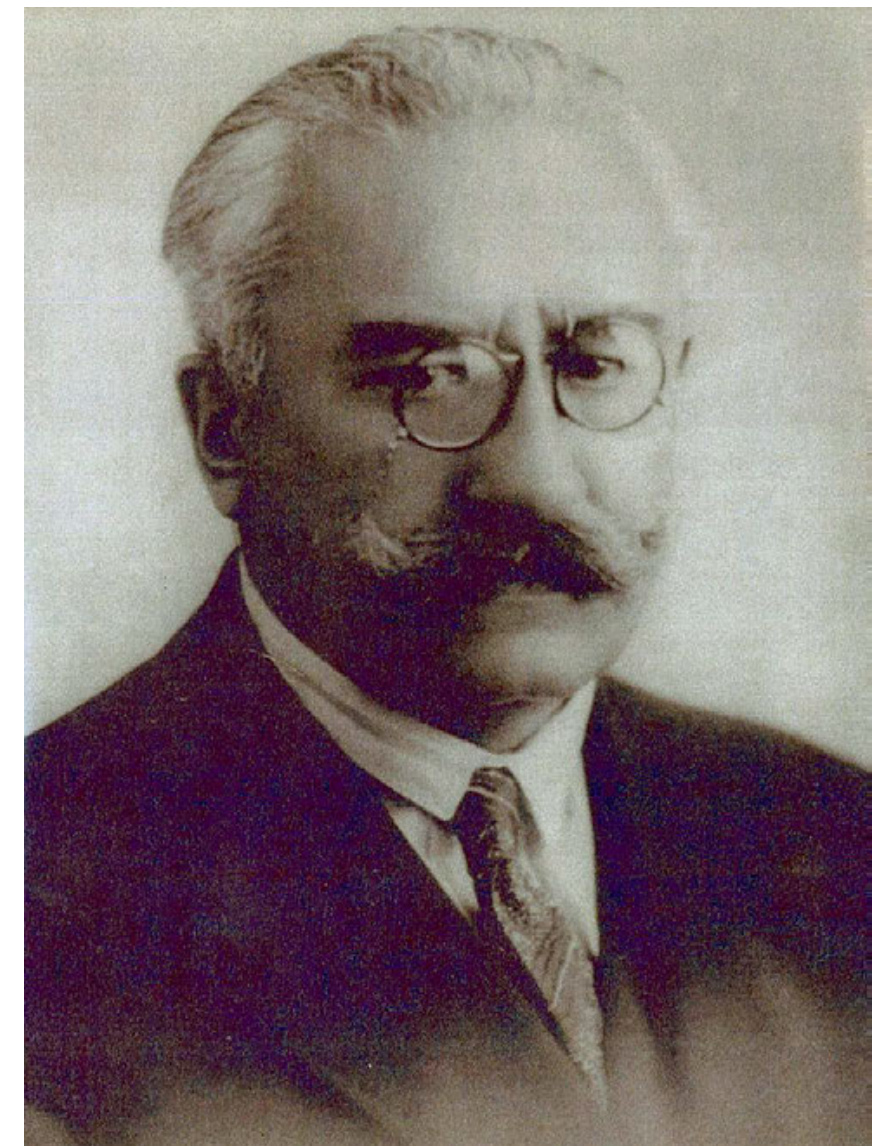

Fig. 3: Alexandru Vaida Voevod, Prime Minister of Romania 1919-1920, 1932, and 1933.

fore. ${ }^{6}$ Only then did the great mass of peasants and city workers, who became politically active with the right to vote, first come to the attention of political parties and leaders, forcing them to think of new provisions in their programmes, new strategies and political messages, in order to obtain the vote of the electoral body, of whom $80 \%$ were now peasants.

The first elections based on the universal vote in the history of Greater Romania took place in November 1919. No political party gained the majority. The National Liberal Party gained 103 representative the Peasant Party 61 representatives, the Romanian National Party of Transylvania won 169 representatives, the Peasant Party of Bessarabia 72 representatives, the Democratic Union Party of Bucovina 27 representatives and the Socialist Party 7 representatives. There were also 22 representatives of ethnic minorities. ${ }^{7}$ Under these circumstances, a "parliamentary bloc' was established, formed mainly from the political parties of the united provinces. The parliamen- 
tary bloc government was chaired by Alexandru Vaida Voevod (1872-1950), leader of the Transylvanian Romanians, appointed prime minister on 1 December 1919.

The elections in November 1919 represented a failure for the old politicians, and it became obvious that, after 1918, the political parties in the Old Romanian Kingdom had to change their entire political strategy. ${ }^{8}$

An analysis of Romania's interwar political life reveals a vital factor: although the parties established before the First World War continued to operate, new ones were beginning to gain power, some coming from the united provinces, some emerging as a result of new, post-war ideological currents and trends. First, the parties in the Old Romanian Kingdom had to win supporters in the united territories. In turn, if they wanted to be actors and decision-makers in the country's politics, regional parties also needed elec-

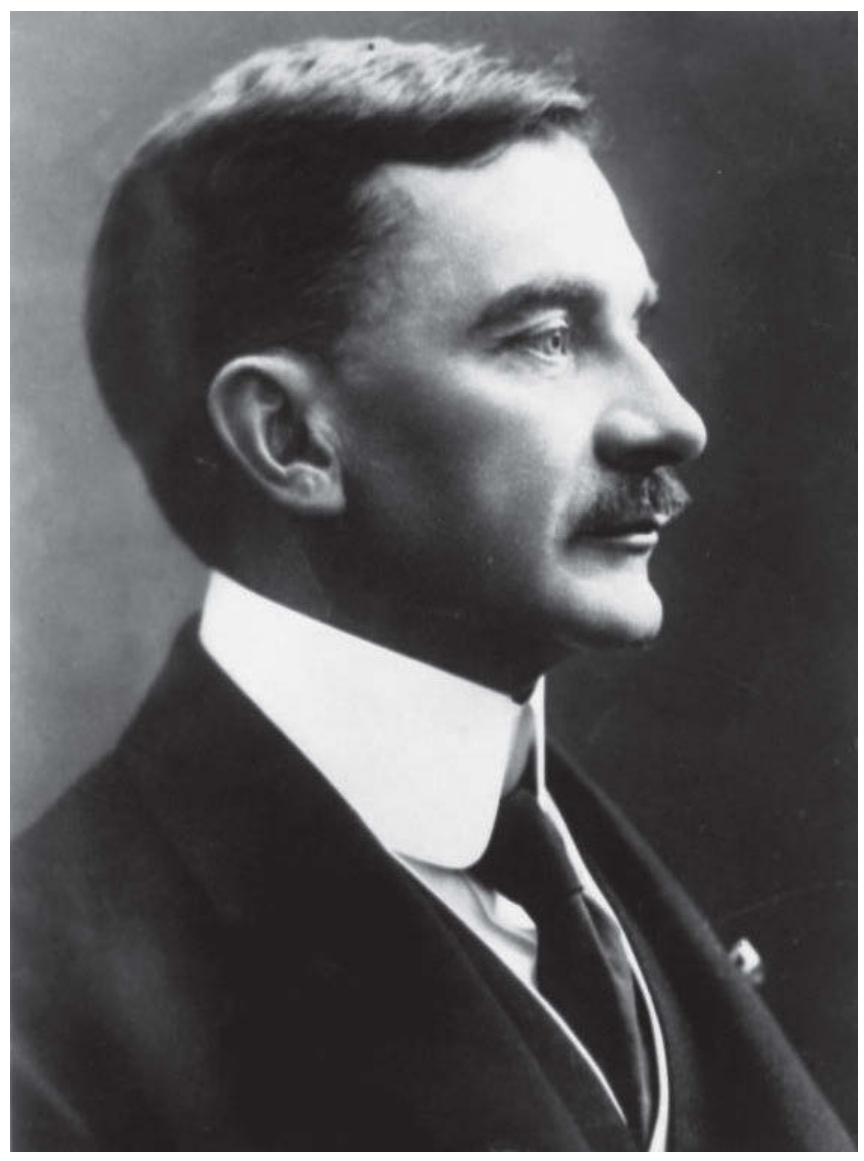

Fig. 4: Iuliu Maniu, head of Transylvania's Directory Council from 2 December 1918. toral support across the country. There was a political expansion in both directions, from the old Romanian Kingdom to the united territories and vice versa, and at least for a while they retained strong influence on their initial mass of voters. The latter phenomenon was most visible during the parliamentary elections in the autumn of 1919, especially in Transylvania where, in the years immediately following the Union, the Romanian National Party (Partidul Naţional Român) and especially its leading personalities continued to enjoy great popularity among their electorate, although the liberal presence was increasingly evident, mainly in urban settings. But, despite the fact that it continued to uphold the democratic principles then promoted at the European level, the Romanian National Party seems to have ended with Transylvania's Union with the Romanian Kingdom. Like the other parties, the Romanian National Party also faced a lack of popularity in other regions of the country. In order to gain votes across the country, the Transylvanians' party needed to fuse with a popular party from the old Kingdom. ${ }^{9}$ After several negotiations and a first short-lived fusion with the Romanian Nationalist Party (Partidul NaţionalistDemocrat) headed by Nicolae Iorga (1871-1940), Iuliu Maniu (1873-1953) turned his attention to the Peasant Party (Partidul Ţărănesc), a party that appeared on the political scene in the Old Romanian Kingdom in 1918, created by a group of teachers, priests and peasants led by Ion Mihalache (1882-1963), and which represented the interests of the rural elites and the small towns of South-Eastern Romania. The Romanian National Party and the Peasant Party merged in October 1926, resulting in the emergence of the country's second largest political party, the National Peasant Party (Partidul Naţional Țărănesc). This party's programme included guaranteeing citizens' rights and freedoms, administrative reform based on decentralisation and local autonomy, removing justice from political influences, granting loans to peasants, developing education, stabilising the monetary situation, recognising rights for workers, and accepting foreign capital..$^{10}$ At the same time, it was the party that, throughout the interwar period, was the most important opposition to the National Liberal Party (Partidul Naţional Liberal).

The National Liberal Party, meanwhile, represented Romania's greatest political power in the in- 
terwar period and ruled the political scene in the first interwar decade. After a short period of organisation and expansion in the newly annexed territories, the liberals ruled between 1922 and 1927, a period that entered Romania's contemporary history as the era of the greatest liberal successes. ${ }^{11}$ The dominant element within the National Liberal Party was the financial elite grouped around the Romanian Bank, headed by the Brătianu family. However, having to take into account the new realities created after 1918, the liberal leaders developed a political programme that required among other things the adoption of a new constitution, administrative and legislative unification, the stabilisation of the economy, and the equality of rights for all citizens. In order to expand its organisation into the united provinces, the National Liberal Party merged with the Peasant Party of Bessarabia (Partidul Ţărănesc din Basarabia) and the Democratic Union Party of Bucovina (Partidul Democrat al Unirii). ${ }^{12}$ In Transylvania, the liberals drew on the collaboration of Romanian, Hungarian and even German elites from the economic, and especially the banking, sector. It was already known that some Transylvanian banking institutions had merged with similar institutions run by elites of the National Liberal Party, and Romanian researchers are beginning to explore this phenomenon. The economic doctrine through which the National Liberal Party promoted its ideology was embodied in its 'by ourselves' politics - namely, the state had to intervene in the economy to protect the indigenous bourgeoisie. In fact, the party, through the political measures it had adopted, wanted to support and promote domestic capital.

Besides the National Liberal Party and the National Peasant Party, there were a number of other political parties in interwar Romania, representing both different political orientations and different ethnic minorities. Yet of the many parties during this time, except for the two major parties analysed above, only a few had come to power, such as the People's Party (Partidul Poporului) and the Nationalist Democratic Party. ${ }^{13}$ For example, the success enjoyed by the People's Party, led by General Alexandru Averescu (1859-1938), was due to the 'Averescu myth', ${ }^{14}$ which appeared on the grounds of dissatisfaction with the liberals who, in the early years of the interwar period, were blamed for all the difficulties the country was going through. Under these circum-

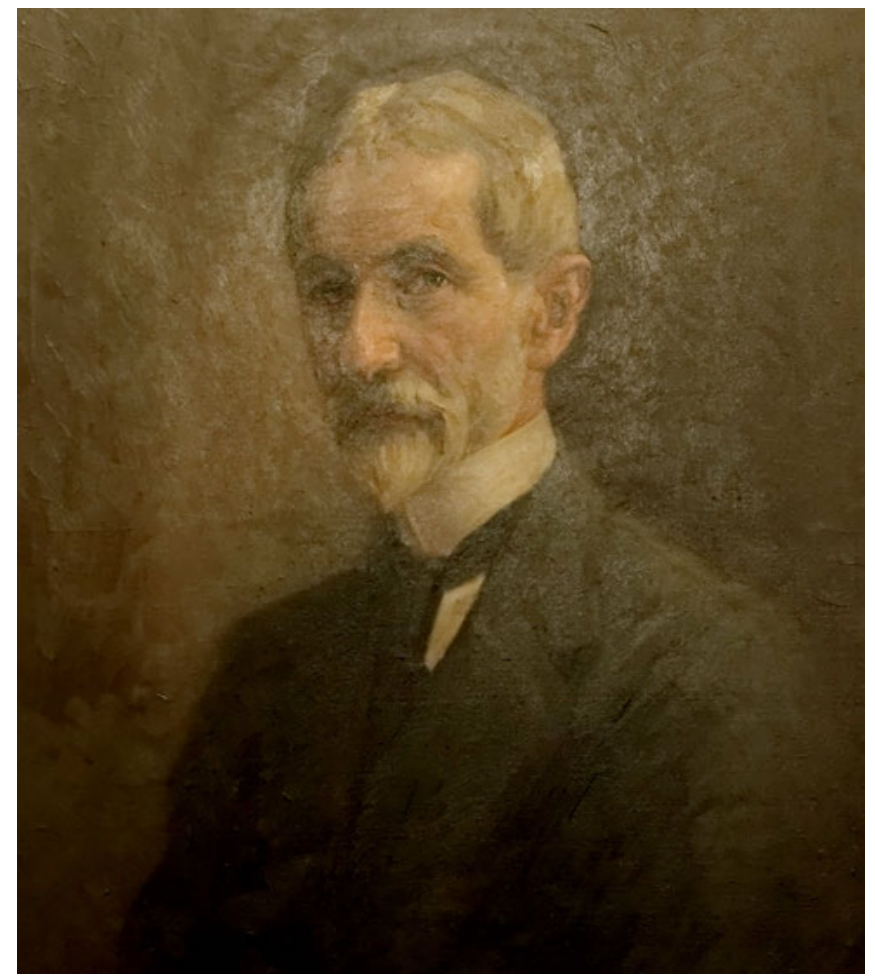

Fig. 5: Alexandru Averescu, army general and Prime Minister of Romania 1918, 1919-1921, and 1926-1927.

stances, a large part of the electorate, especially of the Old Romanian Kingdom, put their hopes in the political formation created by General Alexandru Averescu, whose popularity was growing very high. However, the People's Party was not in government for long, failing to cope with competition from the National Liberal Party and, later, the National Peasant Party. As for the other party mentioned, the Democratic Nationalist Party, whose political agenda focused primarily on the development of education, it found itself in the elite of the Romanian political scene, mainly due to the prestige of its leader, the historian Nicolae Iorga.

The political organisations of the ethnic minorities, including the Hungarian Union (Uniunea Maghiară/Magyar Szövetség), the Hungarian People's Party (Partidul Popular Maghiar/Magyar Néppárt), the Hungarian National Party (Partidul Naţional Maghiar/Magyar Nemzeti Párt) ${ }^{15}$, the German National Party (Deutsche Nationalpartei), the German People's Party (Deutsche Volkspartei), the Union of Germans in Romania (Union der Deutschen in Rumänien), the Swabian People's Party (Schwä- 


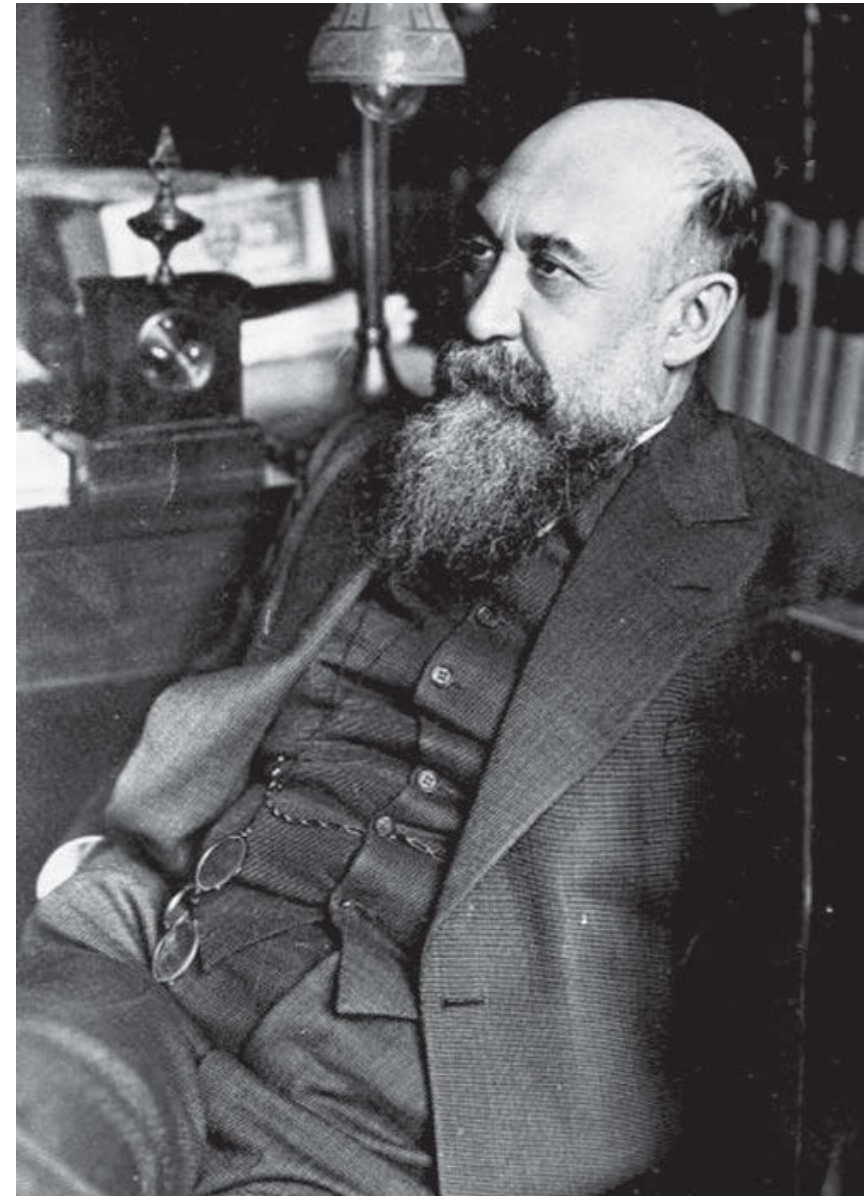

Fig. 6: Nicolae Iorga, historian, politician and poet, President of the Deputies' Assembly and Senate of Romania.

bische Volkspartei), the Romanian Jewish Union (Uniunea Evreilor Români), the Jewish Party (Partidul Evreiesc), ${ }^{16}$ were also active in interwar political life with representatives in Parliament and local administrative structures in Romania and they contributed to the diversification of political life at that time. In fact, the history of the ethnic minorities' parties in interwar Romania was not just political, but also socio-economic and cultural.

At the same time, external influences brought left-wing (such as the Social Democratic Party/Partidul Social-Democrat) and extreme left-wing parties (such as the Romanian Communist Party/Partidul Comunist Român), as well as right-wing (such as the National Christian Party/Partidul Naţional Creștin) and extreme right-wing parties (such as the Legion of the Archangel Michael/Legiunea Arhanghelului Mihail, known after 1930 as the Iron Guard/Garda de fier), to the Romanian political scene, parties that during the interwar period elections did not succeed in winning the necessary number of votes to accede to power. ${ }^{17}$ Only the National Christian Party led by the Transylvanian Octavian Goga (1881-1938) came to power for a few weeks, thanks to King Carol II's (1893-1953) intervention, when no political party gained a majority in the elections of late 1937. But even in that case, it was not genuinely a National Christian government, because the key posts (Internal Affairs, Justice, Foreign Affairs) were entrusted to non-party individuals. The Goga government did not represent a party or coalition of parties, but was instead solely the expression of the royal will. By call-

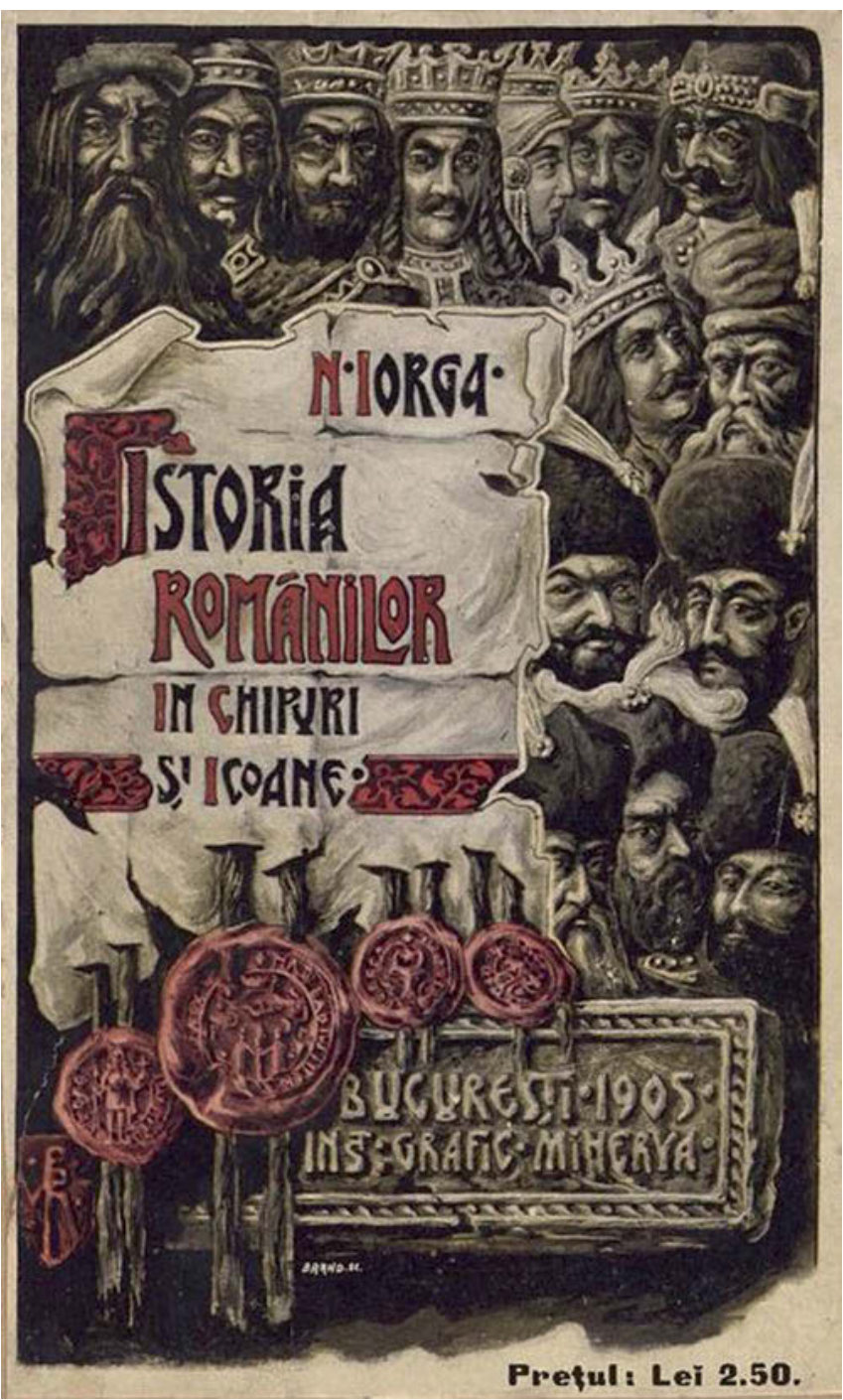

Fig. 7: Book cover of History of Romanians in Faces and Icons (Istoria Romînilor în Chipuri și Icoane) by Nicolae Iorga, first published 1905. 
ing Octavian Goga to power, King Carol II achieved several goals. First, he gave satisfaction to the rightwing current, thus avoiding the rule of the extreme right as represented by the Legionnaires. Secondly, he removed other political opponents, especially the National Peasants of Iuliu Maniu.

As far as the voters' options were concerned, they were extremely contradictory, because a large number of citizens lacked any political culture. They voted according to a certain state of mind, generated by the hopes of a providential man who would hold the perpetrators 'accountable'. Most often, citizens voted because the vote was mandatory and they wanted to avoid a possible fine. Sometimes, voters put their stamp on the front page - which always featured the list of the ruling party. This is why spectacular results have been recorded, none of which could be considered an expression of the electorate's political voice. For example, the National Liberal Party obtained $6.8 \%$ of the votes in 1920 , then $60.3 \%$ in 1922 , dropped to $7.3 \%$ in 1926 and climbed to $61.7 \%$ in 1927. The People's Party registered $42.4 \%$ in 1920, dropped to $6.5 \%$ in 1922 , rose to $52 \%$ in 1926 , then failed to reach the electoral threshold in 1927, as it only gained 1.9\%. In turn, the National Peasant Party won $32.1 \%$ of the votes in 1927 , climbed to $77.7 \%$ in 1923 , to drop to $15 \%$ in $1931 .{ }^{18}$

On the whole, the interwar Romanian political system underwent a series of transformations, including: 1) the dissolution of the conservative parties; 2) the consolidation of the National Liberal Party; 3) the establishment of new parties and their imposition on political life; 4) the integration within the Romanian state of the regional parties that led the movements for the unification of Transylvania, Bucovina and Bessarabia with Romania; 5) the founding of the Peasant National Party; 6) the appearance and affirmation of parties belonging to ethnic minorities; 7) the emergence of extremist organisations. The dynamics of the political parties during the interwar period was as follows: a) between 1918 and 1921 , there was a maximum proliferation of political parties; b) between 1922 and 1926, a fusion trend with a bipolar result: the National Liberal Party and the National Peasant Party; c) between 1927 and 1932, disagreements registered in almost all parties and primarily in the governing ones; d) between 1933 and 1937, the appearance of dissident groups inside

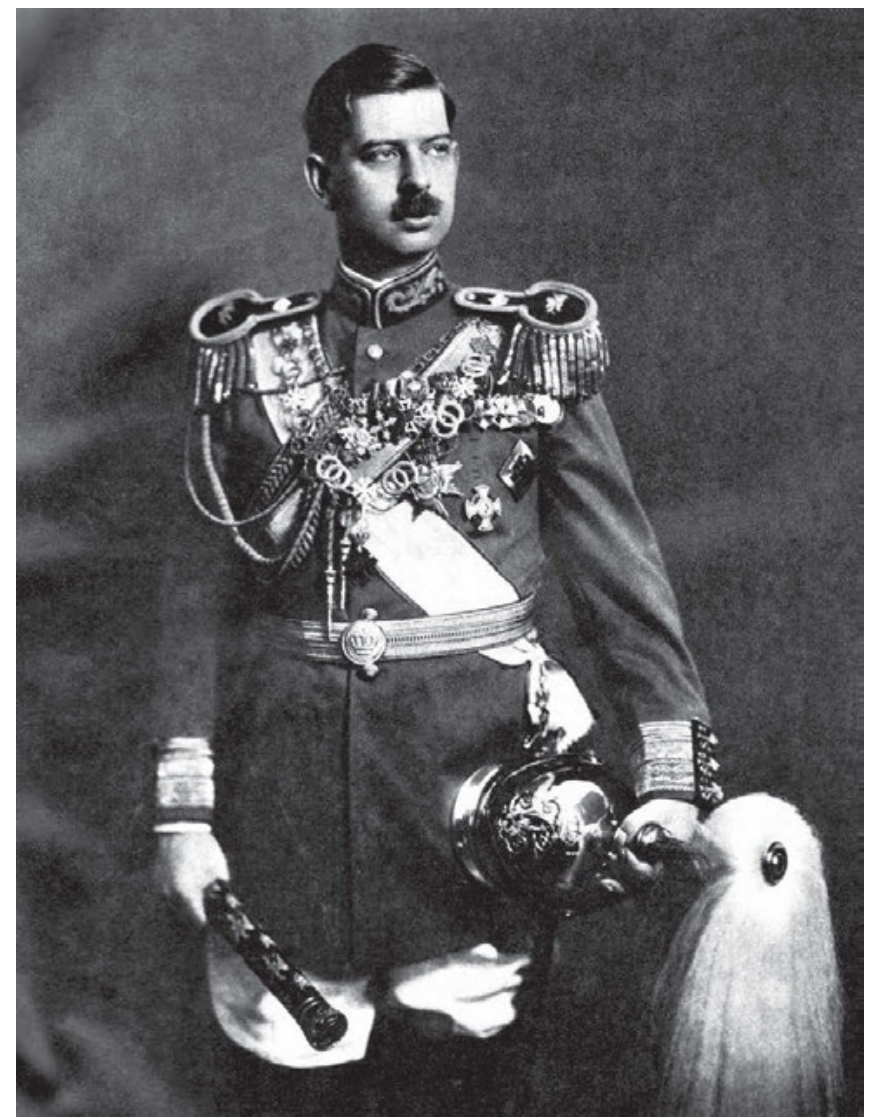

Fig. 8: Romanian King Carol II, regency 1930-1940.

the democratic parties; e) in 1938, the formation of a single party, the National Renaissance Front (only members of this party were able to hold leading positions in the central and in local administrations). ${ }^{19}$

An analysis of the political system and the interwar political dynamics reveals that eleven governments operated during the first decade of the interwar period. Meanwhile, the 1930s characterised by the alternation in power of National Liberals and $\mathrm{Na}-$ tional Peasants. Government changes were followed by the dissolution of the Parliament only when the new cabinet did not belong to the same party.

The European political evolution, and especially the coming to power of extremist regimes in the middle of the interwar period, could not spare Romanian domestic political life. Thus, despite the efforts made to consolidate the new-born state, the domestic political regime began to slip to the right in the second half of the 1930s, as in many other parts of Europe, and the Romanian inter-war democratic regime reached its end in the wake of the outbreak of the 
Second World War. But despite the problems that arose during these twenty years, whether they came to power, or had representatives in Parliament and in the local structures, or fought for a longer or shorter period of time, all political parties in interwar Romania operated in a clearly defined legislative framework, guaranteed by the fundamental state law.

Although the political life of Greater Romania lasted for only two decades, and although it included both smaller and larger errors, it irreversibly put its mark on the administrative, economic, social, and cultural development not only of that period, but of the ones that followed. Progress made in adopting numerous legislative provisions for the modernisation and development of the country, as well as the names and reputations of some political parties and leaders, has remained in the collective memory of the Romanians, despite the regime and the political system that Romania experienced in following decades. Even today, different structures and components of Romanian society will appeal with some nostalgia to the interwar period's models and examples of success.

\section{Endnotes}

1. Vlad Georgescu, Istoria românilor. De la origini pînă în zilele noastre (Bucureşti: Editura Humanitas, 1992), 204.

2. Stephen Fischer-Galati, România în secolul al XX-lea (Iaşi: Institutul European, 1998), 45.

3. Marcela Sălăgean, Introducere în istoria contemporană a României (Cluj-Napoca: Presa Universitară Clujeană, 2013), 10-21. See also Marcela Sălăgean, 'Romania between 1919 and 1947,' in History of Romania. Compendium, eds. Ioan Aurel Pop and Ioan Bolovan (Cluj-Napoca: Institutul Cultural Român, 2006), 583-615, here 586.,

4. For further details, see Keith Hitchins, România 1866-1947 (Bucureşti: Editura Humanitas, 1994), 319-359.

5. Sălăgean, Introducere, 10-20.

6. Hitchins, România 1866-1947, 409. See also: Zigu Ornea, Tradiționalism şi modernitate în deceniul al treilea, (Bucureşti: Editura Eminescu, 1980).

7. Aurel Constantin Soare, Ioan Scurtu and Daiana Fotescu, 'Dinamica structurilor politice,' in Structuri politice în Europa Centrală şi de Est (1918-2001), vol. I, ed. Ioan Scurtu (Bucureşti: Editura Fundatşiei Culturale Române, 2003), 49-88, here 79.

8. Ioan Scurtu and Gheorghe Buzatu, Istoria Românilor în secolul XX (1918-1948) (București: Editura Paideia, 1999), 122-123.

9. Marcela Sălăgean, 'De la România Mare la România Unită. Procesul integrării: teritorii, populaţie, infrastructură, economie,' in Arhivele Totalitarismului, Anul XXVI, no.100101, 3-4 (2018), (Bucureşti: Institutul Naţional pentru studiul totalitarismului, 2018), 62-77, here 72.

10. Ioan Scurtu, Istoria contemporană a României 1918-2001 (Bucureşti: Editura Fundaţiei România de Mâine, 2002), 102.

11. Georgescu, Istoria Românilor, 205.

12. Sălăgean, Introducere, 22.

13. Georgescu, Istoria Românilor, 206.

14. For more details, see: Constantin Argetoianu, Memorii. Pentru cei de mâine. Amintiri din vremea celor de ieri, vol. 6, 19191922 (București: Editura Machiavelli, 1996).

15. For further details, see Tóth Szilárd, 'De la passivism la activism politic - înfiinţarea Partidului Maghiar,' in Multiculturalism în Transilvania după Conferinţa de Pace de la Paris, coord. Marina Trufan, Marius Mureşan, (Cluj-Napoca: Editura Casa Cărții de Știință, 2019), 124-148,

16. Sălăgean, Introducere, 21-30.

17. Ibid.

18. Scurtu and Buzatu, Istoria Românilor, 108.

19. Ibid., 242-249. 